\title{
Teaching English for Specific Purposes: Attitudes among Saudi Engineering Students
}

\author{
Majed Ali Alqahtani ${ }^{1}$ \\ ${ }^{1}$ Department of English, Salman Bin Abdulaziz University, Saudi Arabia \\ Correspondence: Dr. Majed Ali Alqahtani, Department of English, Salman Bin Abdulaziz University, Al-Kharj \\ 11942, Saudi Arabia. Tel: 966-552-888-867. E-mail: mn.algahtani@sau.edu.sa
}

Received: March 16, 2015 Accepted: April 24, 2015 Online Published: June 29, 2015

doi:10.5539/elt.v8n7p76 URL: http://dx.doi.org/10.5539/elt.v8n7p76

\begin{abstract}
Attitude is considered as one of the most crucial factors for learning a second or foreign language for a specific purpose. It plays a major role in arousing student's interest and motivation towards learning. The main purpose for conducting this research is to identify the attitude among engineering students in Saudi Arabia towards learning English for a specific purpose. This research used qualitative and quantitative methods. Surveys were conducted from students of a Saudi Engineering university; furthermore teachers and mentors were interviewed to analyze the attitudes of students towards learning English. Findings suggest negative attitudes towards learning English. Interviews however identified several ways through which attitudes of students can positively change towards learning English for specific purpose. It could be concluded that although the number of students having positive attitude towards learning English is a handful but it could significantly be improved through introducing advanced language course and enhanced instructional methods to motivate students towards learning English for specific purpose. Finally, some implications would help in tapping motivation of students and changing their attitudes.
\end{abstract}

Keywords: cognitive traits, cultural integration, multi-lingual, tolerance to ambiguity

\section{Introduction}

English has become one of the most important languages for communicating in the world today. Teaching English as a foreign language has a long history in many countries and it has been spread in different parts of Arab Countries. English is a very important language in present times as it enhances an individual's ability to learn more and used as a primary mode of communication. However, student's attitude and proficiency in English has not been motivating. The research study of Amuzie and Winkie (2009) analyzed that students have a general assumption related to themselves as learners of second language. This study identifies the same assumption in Saudi Engineering students that could be considered as their reluctant attitude towards learning English.

\subsection{Background of the Study}

Over the past four decades, a question has arisen related to discovering the motivation, attitudes and learning abilities of students especially for the second language i.e. English. The research study of Barcelos and Kalaja (2011) stated that it depends upon the learners how they go about the learning process. Consequently, they may account for differences in their success. The research study of Bateman (2008) has stated that belief of students depend upon the expectation, commitment, success and satisfaction with a particular learning context. Second language learner expectations are underpin through the beliefs that are shaped in terms of their cultural backgrounds and past experiences (Borg, 2011). Internet and media has made it easy for the learners to acquire new language that has an impact on the beliefs or attitudes of individuals within the economy of Saudi Arabia. It was also found in the research study of Bernat et al. (2009) learning independently is another factor that effects on beliefs as this methods does not exist in Saudi Education system. Therefore, trends have been changing related to the attitude of students for learning English as a second language especially due to its global presence.

\subsection{Research Aim and Objectives}

The main focus of the researchers is to conduct an analysis related to the attitude of Saudi Engineering Students for learning English as their second language. Further, the research has potentials for achieving the following 
objectives. These are:

- To understand the significance of English language in Education;

- To focus on Saudi engineering students behavior towards English Language;

- To find out the outcome of learning English as a second language; and

- To find out ways through which Engineering students are motivated toward learning English; and

- To provide recommendations for enhancing or motivating Saudi engineering students for learning English as a second language.

\subsection{Significance of the Study}

This research study is significant in finding out the fact that students need to have motivation and positive attitude so that they are able to learn new things occurring within the changing environment. This research is also relevant in defining the language learning beliefs that are required for learning English. This research will identify whether engineering students adopt a similar strategy for learning English as a second language, despite having previous experience of instructional and independent learning contexts.

\section{Method}

\subsection{Research Design}

Methodology is one of the most essential sections within a research. It has been identified that researchers utilize both qualitative and quantitative approach towards this study. There are several reasons due to which both qualitative and quantitative information is included in this research. Qualitative method of research has several advantages such as it is one of the easiest data collection tools. Descriptive nature of qualitative data facilitates in explaining the topic with details, provide proper reasoning and drawing conclusions related to the research topic. On the other hand, quantitative information provides numbers that increases authenticity of the research. Numerical data is then interpreted according to the need of the research topic.

There are different techniques or tools through which qualitative and quantitative information is gathered. This research gathers literature from secondary sources whereas primary techniques are used for gathering first hand information related to the topic of this research. Questionnaires and interviews facilitated researchers to collect quantitative and qualitative data. Questionnaires distributed were open-ended questions encouraged students to formulate their own ideas on what it takes to learn a language, and whether the necessary conditions were provided by the university context. Therefore, qualitative data thus generated in-depth insights into business students' cognitions, and to show what kind of perceptions dominate among the student population considered for this research.

\subsection{Sample Size and Selection Criteria}

The questionnaire included 36 items that included questions to explore the beliefs and learning strategies engineering students rank highly, and establishes significant differences, if any, between the three cohorts. It thus lays the groundwork for establishing how these Engineering students experience and interpret language learning. Thus, a phenomenon graphic approach was adopted on the basis of which open-ended survey questions and interviews were developed. The research study of Maxwell (2012) has defined that phenomenography is the empirical study which is able to identify the ways in which people, their experiences and concepts differ in many ways and aspects of the world around us. Thus, majority of the qualitative part in the study seeks to contextualize belief patterns of students learning English language. Further, findings of the study will also be able to identify the consequences in terms of students' approaches towards studying and assessment of the engineering English classes. Thus, a mixed methodological approach will be used to achieve the main purpose of this research.

\section{Results}

The result section is divided between the results that were generated from the survey conducted and interviews from a relevant sample population considered for this research. Open ended questions were included in survey that was able to illustrate the changes in attitude as a result of learning English for Specific Purpose. Among the entire population only 8 individuals were non responsive of the survey questions. Questionnaire was divided into two parts i.e. Belief Domain and Strategies. 
Table 1. You shouldn't say anything in a foreign language until you can say it correctly

\begin{tabular}{lllllll}
\hline & & Frequency & Percent & Valid Percent & Cumulative Percent & Average \\
\hline \multirow{6}{*}{ Valid } & 1.00 & 116 & 30.8 & 30.8 & 30.8 & \\
& 2.00 & 38 & 10.1 & 10.1 & 40.8 & \\
& 3.00 & 97 & 25.7 & 25.7 & 66.6 & 2.82 \\
& 4.00 & 48 & 12.7 & 12.7 & 79.3 & \\
& 5.00 & 78 & 20.7 & 20.7 & 100.0 & \\
& Missing & & & & & \\
& Total & 377 & 100.0 & 100.0 & & \\
\hline
\end{tabular}

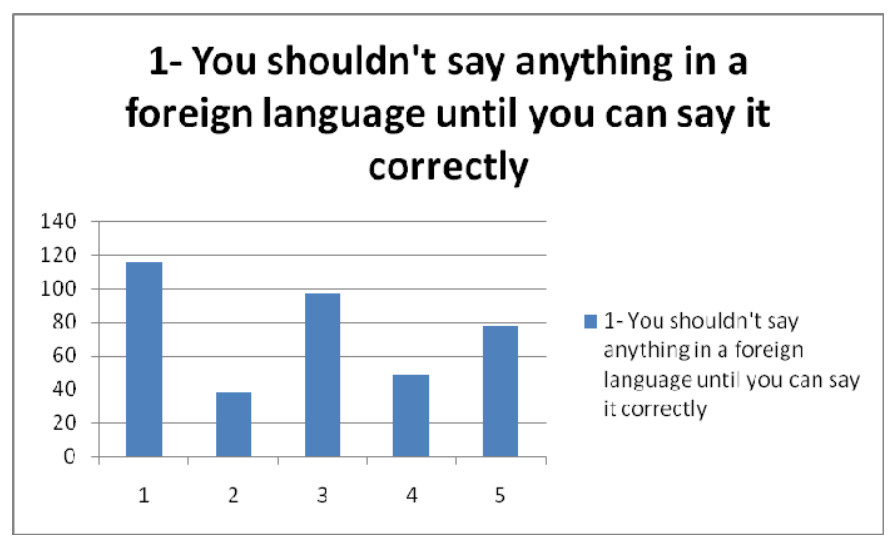

Figure 1. You shouldn't say anything in a foreign language until you can say it correctly

The tables illustrate the responses of 116 sample population, one of the major finding suggest that students attitude towards speaking English is that one should not say anything in foreign language until one can say it properly. It was also identified by majority of the respondents that individuals should try to learn from the English conversation on their own irrespective of the mistakes made by an individual. It was also inquired that respondents can use movies or use native speakers in order to learn English. However, respondents agreed that Saudi Students do worry about the mistakes.

As the Table 2 shows, that it was also answered by 78 people that it will become difficult for individuals to overcome their mistakes in the long run.

Table 2. I learn something from using English in conversations even if nobody corrects the mistakes I make

\begin{tabular}{lllllll}
\hline & & Frequency & Percent & Valid Percent & Cumulative Percent & Average \\
\hline \multirow{6}{*}{ Valid } & 1.00 & 153 & 40.6 & 40.6 & 40.6 & \\
& 2.00 & 73 & 19.4 & 19.4 & 59.9 & \\
& 3.00 & 83 & 22.0 & 22.0 & 82.0 & 2.25 \\
& 4.00 & 28 & 7.4 & 7.4 & 89.4 & \\
& 5.00 & 36 & 9.5 & 9.5 & 98.9 & \\
& Missing & & & & & \\
& Total & 377 & 100.0 & 100.0 & & \\
\hline
\end{tabular}




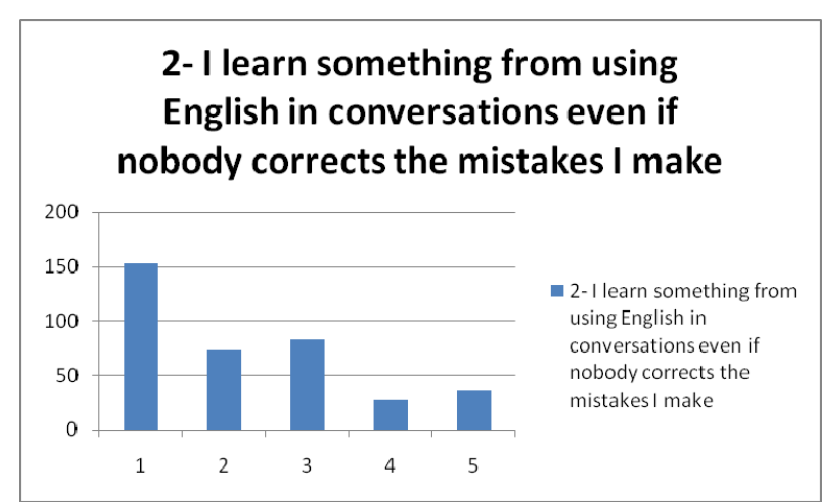

Figure 2. I learn something from using English in conversations even if nobody corrects the mistakes I make

Moreover, it was also identified from the results shown in the tables that there are different grammatical errors that need to be considered by individuals while speaking English with the members of a community.

Table 3. There is not much point in group work activities if you do not present the results in front of the teacher

\begin{tabular}{lllllll}
\hline & & Frequency & Percent & Valid Percent & Cumulative Percent & Average \\
\hline \multirow{6}{*}{ Valid } & 1.00 & 126 & 33.4 & 33.4 & 33.4 & \\
& 2.00 & 68 & 18.0 & 18.0 & 51.5 & \\
& 3.00 & 107 & 28.4 & 28.4 & 79.8 & 2.48 \\
& 4.00 & 28 & 7.4 & 7.4 & 87.3 & \\
& 5.00 & 48 & 12.7 & 12.7 & 100.0 & \\
& Missing & & & & & \\
& Total & 377 & 100.0 & 100.0 & & \\
\hline
\end{tabular}

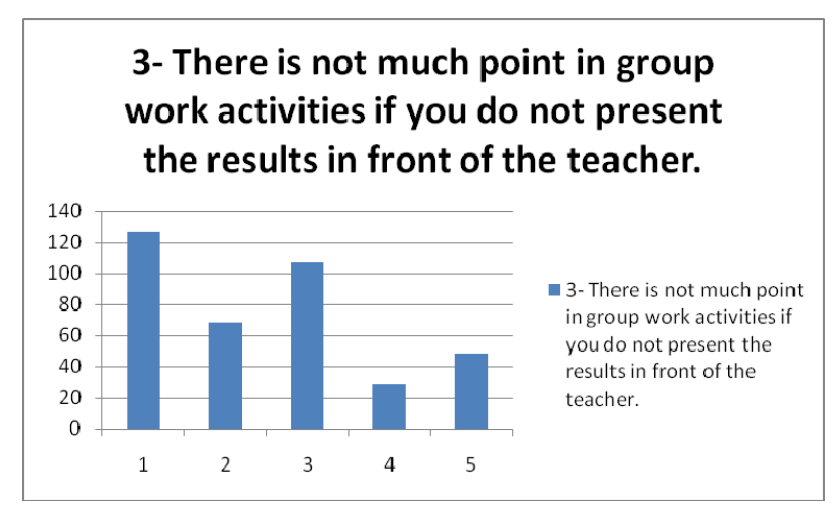

Figure 3. There is not much point in group work activities if you do not present the results in front of the teacher

Table 4. I learn something from watching films or listening to native speakers even if I don't understand everything

\begin{tabular}{lllllll}
\hline & & Frequency & Percent & Valid Percent & Cumulative Percent & Average \\
\hline \multirow{6}{*}{ Valid } & 1.00 & 134 & 35.5 & 35.5 & 35.5 & \\
& 2.00 & 146 & 38.7 & 38.7 & 74.3 & \\
& 3.00 & 46 & 12.2 & 12.2 & 86.5 & 2.12 \\
& 4.00 & 21 & 5.6 & 5.6 & 92.0 & \\
& 5.00 & 30 & 8.0 & 8.0 & 100.0 & \\
& Missing & & & & & \\
& Total & 377 & 100.0 & 100.0 & & \\
\hline
\end{tabular}




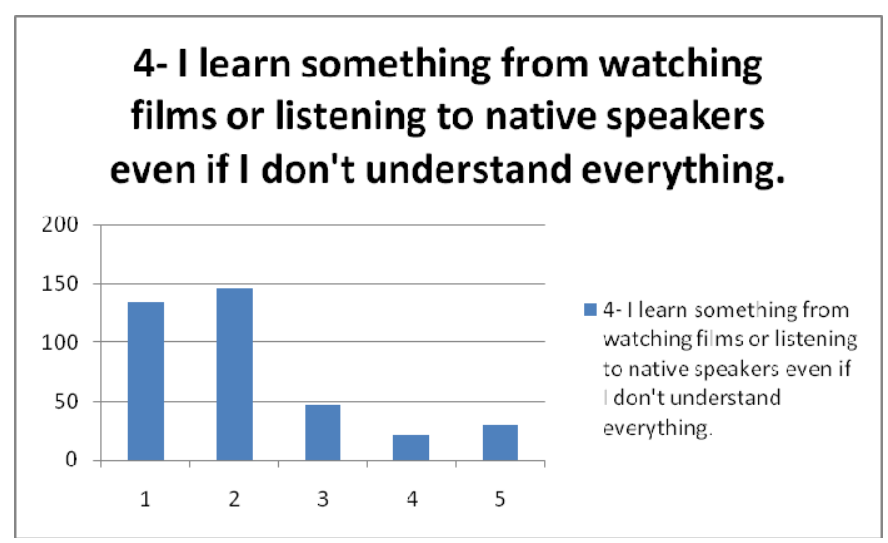

Figure 4. I learn something from watching films or listening to native speakers even if I don't understand everything

Table 5. I do worry about making mistakes in English

\begin{tabular}{lllllll}
\hline & & Frequency & Percent & Valid Percent & Cumulative Percent & Average \\
\hline \multirow{4}{*}{ Valid } & 1.00 & 100 & 26.5 & 26.5 & 26.5 & \\
& 2.00 & 69 & 18.3 & 18.3 & 44.8 & \\
& 3.00 & 103 & 27.3 & 27.3 & 72.1 & 2.67 \\
& 4.00 & 54 & 14.3 & 14.3 & 86.5 & \\
& 5.00 & 46 & 12.2 & 12.2 & 98.7 & \\
& Missing & & & & & \\
& Total & 377 & 100.0 & 100.0 & & \\
\hline
\end{tabular}

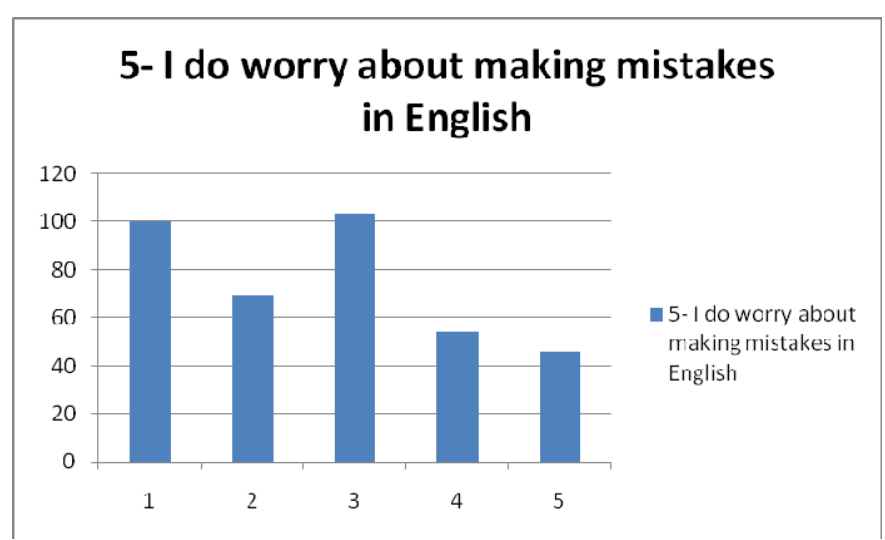

Figure 5. I do worry about making mistakes in English

Table 6. If you are allowed to make mistakes in the beginning, it will be hard to get rid of them later on

\begin{tabular}{lllllll}
\hline & & Frequency & Percent & Valid Percent & Cumulative Percent & Average \\
\hline \multirow{6}{*}{ Valid } & 1.00 & 78 & 20.7 & 20.7 & 20.7 & \\
& 2.00 & 45 & 11.9 & 11.9 & 32.6 & \\
& 3.00 & 101 & 26.8 & 26.8 & 59.4 & 2.97 \\
& 4.00 & 108 & 28.6 & 28.6 & 88.1 & \\
& 5.00 & 40 & 10.6 & 10.6 & 98.7 & \\
& Missing & & & & & \\
& Total & 377 & 100.0 & 100.0 & & \\
\hline
\end{tabular}




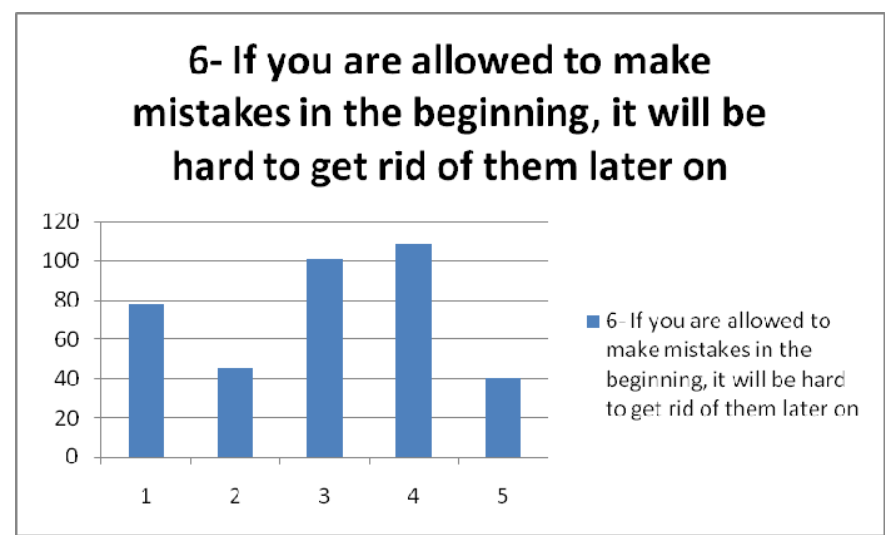

Figure 6. If you are allowed to make mistakes in the beginning, it will be hard to get rid of them later on

As mentioned in the Table 7, there were 123 respondents who agreed to guess if an individual is unable to understand the word of a foreign language. On the other hand, it was agreed by 137 individuals (Table 10) that they start to panic when they are asked to speak in English without any preparations. Similarly, there were students who were uncertain about their views related to the consciousness that is present among the Saudi students related to speaking in English in front of other students. There were 129 students (Table 13) who had stated that they like to interact with other students in English class.

Table 7. I prefer to say what I want in English without worrying about the small details of grammar

\begin{tabular}{lllllll}
\hline & & Frequency & Percent & Valid Percent & Cumulative Percent & Average \\
\hline \multirow{6}{*}{ Valid } & 1.00 & 123 & 32.6 & 32.6 & 32.6 & \\
& 2.00 & 94 & 24.9 & 24.9 & 57.6 & \\
& 3.00 & 91 & 24.1 & 24.1 & 81.7 & 2.36 \\
& 4.00 & 36 & 9.5 & 9.5 & 91.2 & \\
& 5.00 & 32 & 8.5 & 8.5 & 99.7 & \\
& Missing & & & & & \\
\hline
\end{tabular}

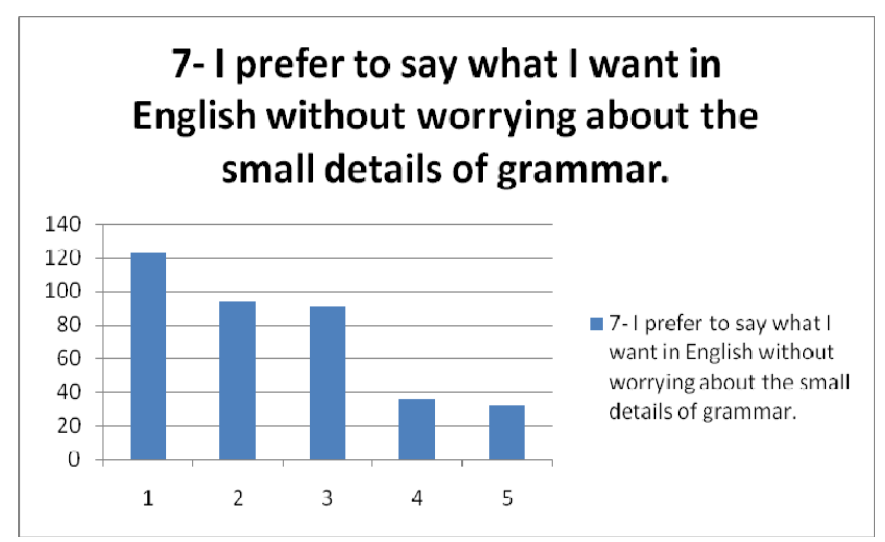

Figure 7. I prefer to say what I want in English without worrying about the small details of grammar 
Table 8. It is okay to guess if you do not know a word in the foreign language

\begin{tabular}{lllllll}
\hline & & Frequency & Percent & Valid Percent & Cumulative Percent & Average \\
\hline \multirow{6}{*}{ Valid } & 1.00 & 129 & 35.3 & 35.3 & 35.3 & \\
& 2.00 & 69 & 18.9 & 18.9 & 54.2 & \\
& 3.00 & 104 & 28.5 & 28.5 & 82.7 & 2.36 \\
& 4.00 & 32 & 8.8 & 8.8 & 91.5 & \\
& 5.00 & 31 & 8.5 & 8.5 & 100.0 & \\
& Missing & & & & & \\
& Total & 377 & 100.0 & 100.0 & & \\
\hline
\end{tabular}

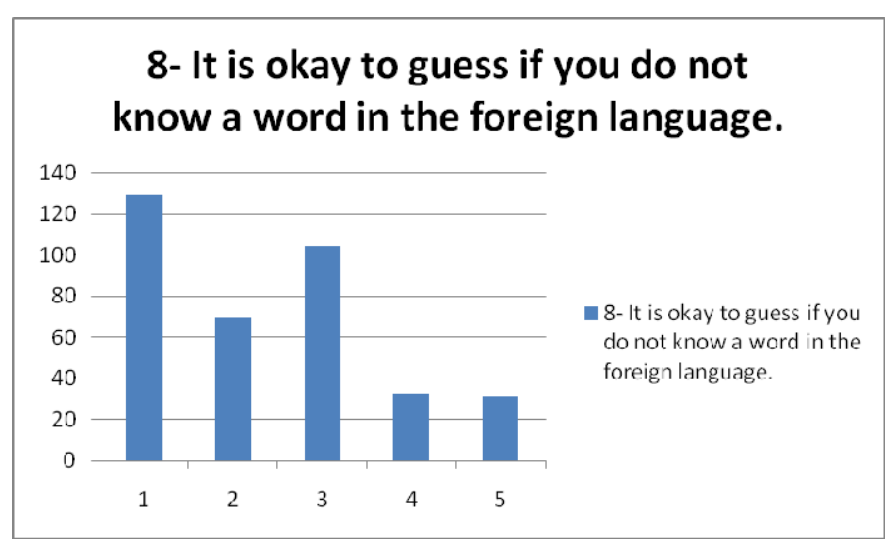

Figure 8. It is okay to guess if you do not know a word in the foreign language

Table 9. I never feel quite sure of myself when I am speaking English in class

\begin{tabular}{lllllll}
\hline & & Frequency & Percent & Valid Percent & Cumulative Percent & Average \\
\hline \multirow{6}{*}{ Valid } & 1.00 & 99 & 27.0 & 27.0 & 27.0 & \\
& 2.00 & 74 & 20.2 & 20.2 & 47.3 & \\
& 3.00 & 82 & 22.4 & 22.4 & 69.7 & 2.71 \\
& 4.00 & 56 & 15.3 & 15.3 & 85.0 & \\
& 5.00 & 55 & 15.0 & 15.0 & 100.0 & \\
& Missing & & & & & \\
& Total & 377 & 100.0 & 100.0 & & \\
\hline
\end{tabular}

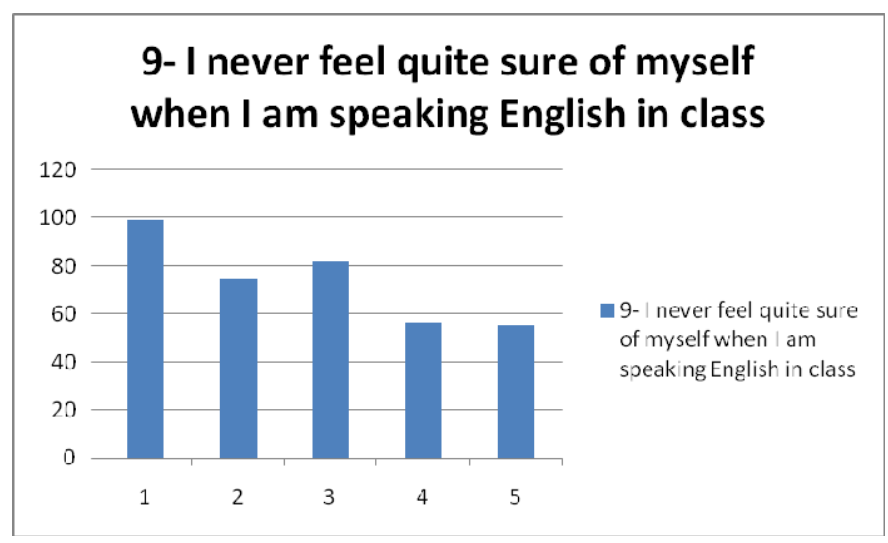

Figure 9. I never feel quite sure of myself when I am speaking English in class 
Table 10. I start to panic when I have to speak without preparation

\begin{tabular}{lllllll}
\hline & & Frequency & Percent & Valid Percent & Cumulative Percent & Average \\
\hline \multirow{6}{*}{ Valid } & 1.00 & 137 & 36.4 & 36.4 & 36.4 & \\
& 2.00 & 77 & 20.5 & 20.5 & 56.9 & \\
& 3.00 & 74 & 19.7 & 19.7 & 76.6 & 2.43 \\
& 4.00 & 39 & 10.4 & 10.4 & 87.0 & \\
& 5.00 & 49 & 13.0 & 13.0 & 100.0 & \\
& Missing & & & & & \\
& Total & 377 & 100.0 & 100.0 & & \\
\hline
\end{tabular}

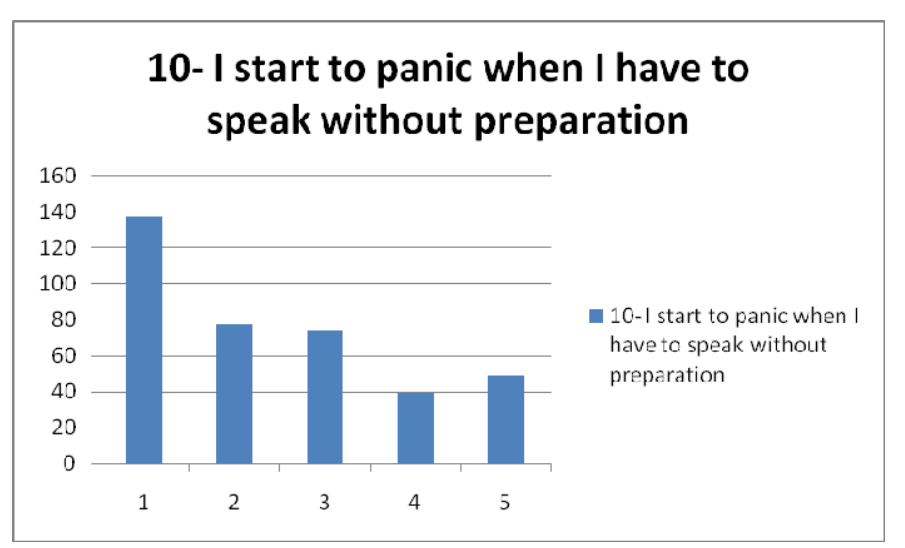

Figure 10. I start to panic when I have to speak without preparation

Table 11. I feel self-conscious about speaking English in front of other students

\begin{tabular}{lllllll}
\hline & & Frequency & Percent & Valid Percent & Cumulative Percent & Average \\
\hline \multirow{4}{*}{ Valid } & 1.00 & 66 & 17.6 & 17.6 & 17.6 & \\
& 2.00 & 53 & 14.1 & 14.1 & 31.6 & \\
& 3.00 & 113 & 30.1 & 30.1 & 61.7 & 3.06 \\
& 4.00 & 79 & 21.0 & 21.0 & 82.7 & \\
& 5.00 & 65 & 17.3 & 17.3 & 100.0 & \\
& Missing & & & & & \\
& Total & 377 & 100.0 & 100.0 & & \\
\hline
\end{tabular}

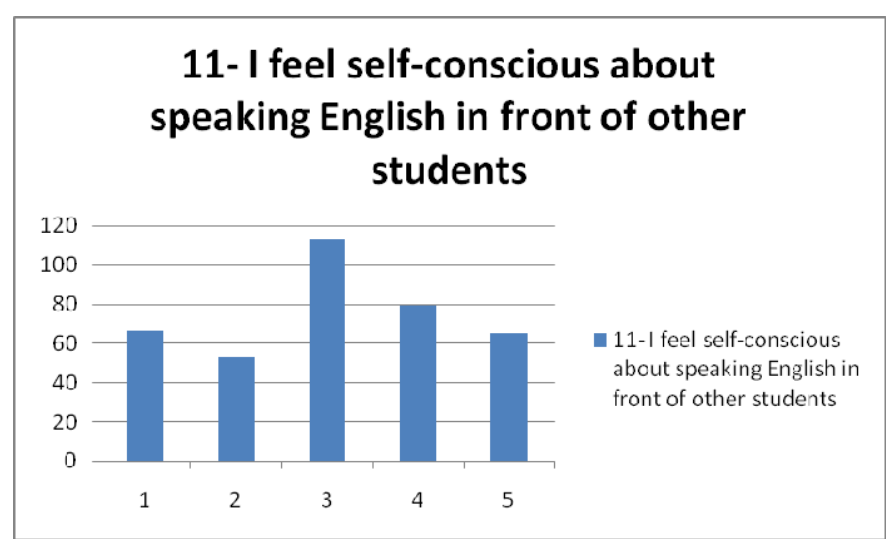

Figure 11. I feel self-conscious about speaking English in front of other students 
Table 12. I keep thinking that the other students are better at English than me

\begin{tabular}{lllllll}
\hline & & Frequency & Percent & Valid Percent & Cumulative Percent & Average \\
\hline \multirow{6}{*}{ Valid } & 1.00 & 66 & 39.6 & 39.6 & 39.6 & \\
& 2.00 & 70 & 23.7 & 23.7 & 63.3 & \\
& 3.00 & 133 & 20.1 & 20.1 & 83.4 & 2.19 \\
& 4.00 & 40 & 4.2 & 4.2 & 87.6 & \\
& 5.00 & 65 & 9.8 & 9.8 & 97.4 & \\
& Missing & & & & & \\
& Total & 377 & 100.0 & 100.0 & & \\
\hline
\end{tabular}

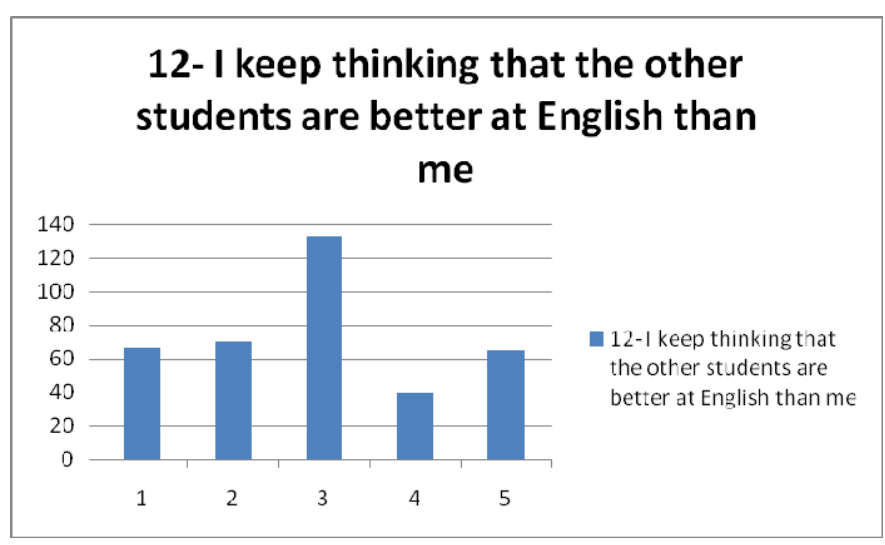

Figure 12. I keep thinking that the other students are better at English than me

Table 13. I enjoy interacting with the other students in English classes

\begin{tabular}{lllllll}
\hline & & Frequency & Percent & Valid Percent & Cumulative Percent & Average \\
\hline \multirow{6}{*}{ Valid } & 1.00 & 129 & 34.9 & 34.9 & 34.9 & \\
& 2.00 & 65 & 17.6 & 17.6 & 52.4 & \\
& 3.00 & 115 & 31.1 & 31.1 & 83.5 & 2.19 \\
& 4.00 & 26 & 7.0 & 7.0 & 90.5 & \\
& 5.00 & 35 & 9.5 & 9.5 & 100.0 & \\
& Missing & & & & & \\
& Total & 377 & 100.0 & 100.0 & & \\
\hline
\end{tabular}

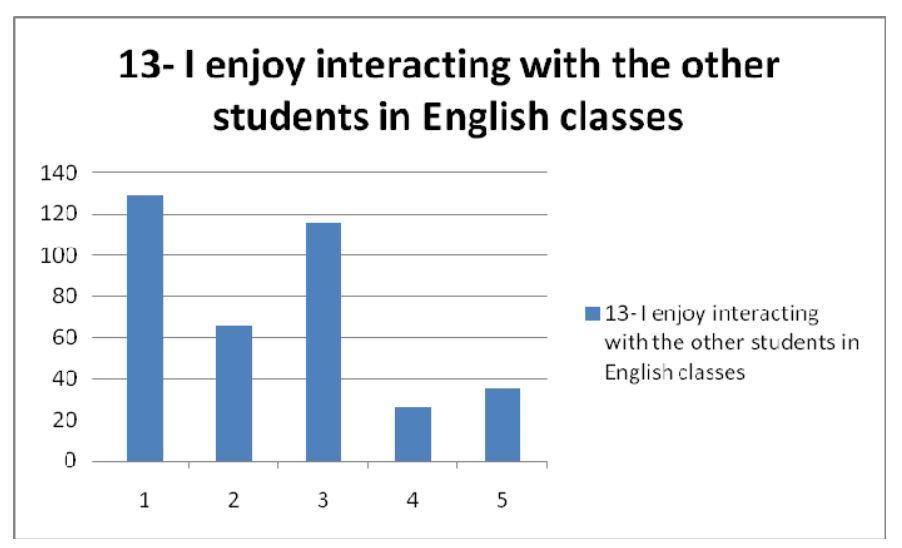

Figure 13. I enjoy interacting with the other students in English classes 
On the other hand, second part of the questionnaire discussed strategies that play a positive role in changing the attitude of especially Engineering Students in Saudi Arabia. Table 14 in shows that there were 194 persons of the individuals agreed that it is essential for planning the studies in the days to come. At the same time there were 118 individuals (Table 15) who stated that students determine optimal ways of learning. Students agreed on the fact that students should keep reviewing the progress regularly so that they are interconnected with the progress made in the educational fields all over the world. It was evident from the agreeing behavior of the respondents that students always focus on identifying mistakes while they use English language for communicating with other individuals of the society. Table 21 shows that there were 118 students who stated that they had a positive attitude towards learning English language as individuals try to break the words into parts that they can identify so that they can understand a word.

Table 14. It is important to plan one's studying carefully

\begin{tabular}{lllllll}
\hline & & Frequency & Percent & Valid Percent & Cumulative Percent & Average \\
\hline \multirow{6}{*}{ Valid } & 1.00 & 63 & 16.7 & 17.7 & 17.7 \\
& 2.00 & 194 & 51.5 & 54.5 & 72.2 \\
& 3.00 & 74 & 19.6 & 20.8 & 93.0 & 1.85 \\
& 4.00 & 17 & 4.5 & 4.8 & 97.8 & 100.0 \\
\\
& 5.00 & 8 & 2.1 & 2.2 & \\
\hline
\end{tabular}

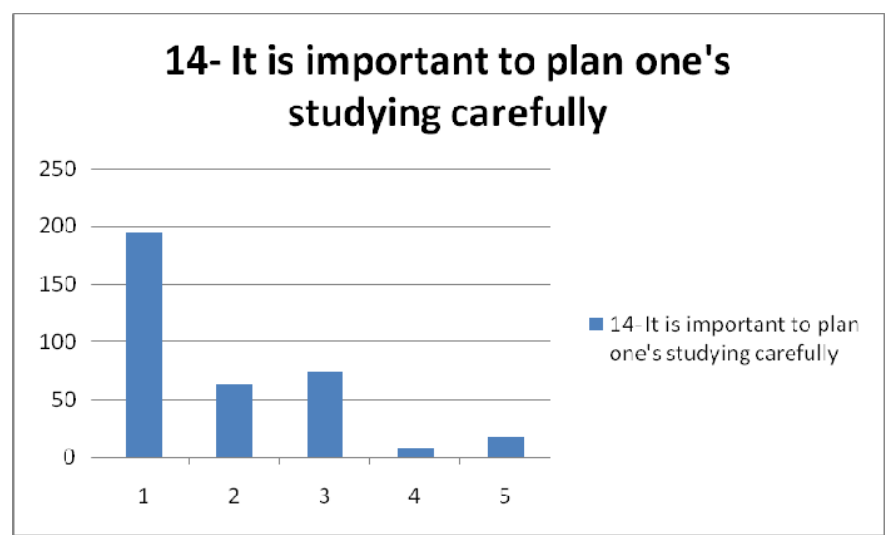

Figure 14. It is important to plan one's studying carefully

Table 15. It is up to me to determine optimal ways of learning

\begin{tabular}{lllllll}
\hline & & Frequency & Percent & Valid Percent & Cumulative Percent & Average \\
\hline \multirow{4}{*}{ Valid } & 1.00 & 76 & 20.2 & 20.8 & 20.8 & \\
& 2.00 & 118 & 31.3 & 32.3 & 53.2 & \\
& 3.00 & 106 & 28.1 & 29.0 & 82.2 & 2.52 \\
& 4.00 & 37 & 9.8 & 10.1 & 92.3 & \\
& 5.00 & 28 & 7.4 & 7.7 & 100.0 & \\
\hline
\end{tabular}




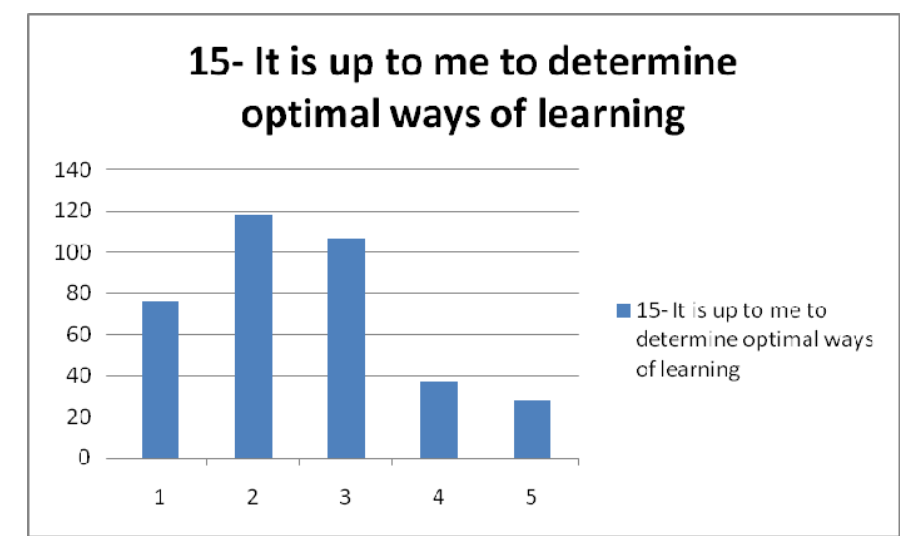

Figure 15. It is up to me to determine optimal ways of learning

Table 16. It is important to review one's progress regularly

\begin{tabular}{lllllll}
\hline & & Frequency & Percent & Valid Percent & Cumulative Percent & Average \\
\hline \multirow{4}{*}{ Valid } & 1.00 & 139 & 36.9 & 38.1 & 38.1 & \\
& 2.00 & 107 & 28.4 & 29.3 & 67.4 & \\
& 3.00 & 99 & 26.3 & 27.1 & 94.5 & 2.02 \\
& 4.00 & 12 & 3.2 & 3.3 & 97.8 & \\
& 5.00 & 8 & 2.1 & 2.2 & 100.0 & \\
& Missing & 12 & 3.2 & & & \\
& Total & 377 & 100.0 & 100.0 & & \\
\hline
\end{tabular}

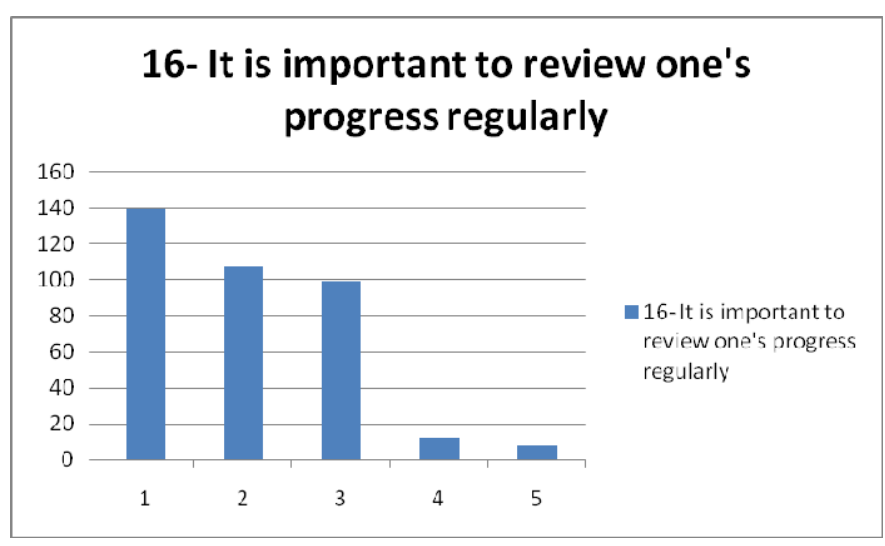

Figure 16. It is important to review one's progress regularly

Table 17. It is up to me to find out my weaknesses are and what to do about them

\begin{tabular}{lllllll}
\hline & & Frequency & Percent & Valid Percent & Cumulative Percent & Average \\
\hline \multirow{6}{*}{ Valid } & 1.00 & 147 & 40.3 & 39.3 & 39.3 & \\
& 2.00 & 81 & 22.2 & 21.7 & 61.0 & \\
& 3.00 & 62 & 17.0 & 16.6 & 77.5 & 2.33 \\
& 4.00 & 30 & 8.2 & 8.0 & 85.6 & \\
& 5.00 & 48 & 13.2 & 12.8 & 100.4 & \\
& Missing & & & & & \\
& Total & 377 & 100.0 & 100.0 & & \\
\hline
\end{tabular}




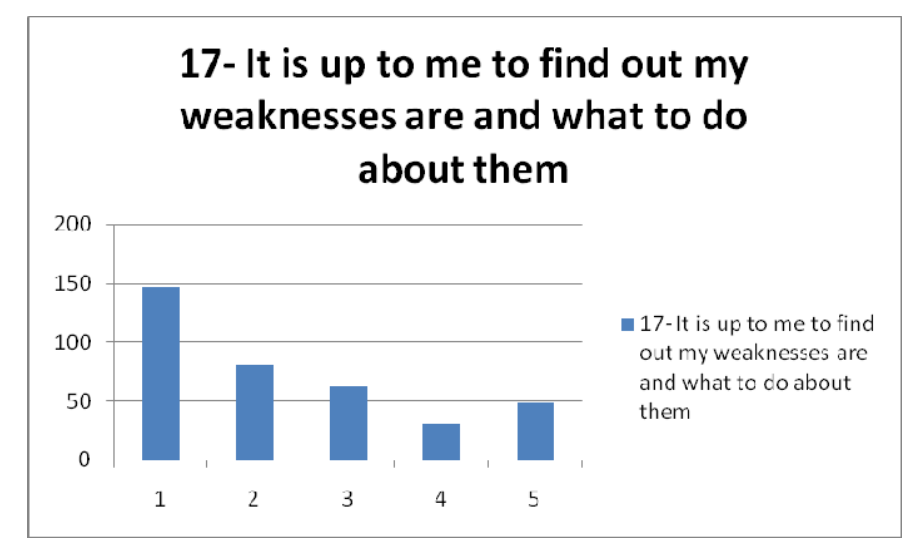

Figure 17. It is up to me to find out my weaknesses are and what to do about them

Table 18. I always pay attention to grammatical correctness when I use English

\begin{tabular}{lllllll}
\hline & & Frequency & Percent & Valid Percent & Cumulative Percent & Average \\
\hline \multirow{6}{*}{ Valid } & 1.00 & 105 & 28.1 & 28.3 & 28.3 & \\
& 2.00 & 63 & 16.8 & 17.0 & 45.3 & \\
& 3.00 & 82 & 21.9 & 22.1 & 67.4 & 2.78 \\
& 4.00 & 43 & 11.5 & 11.6 & 79.0 & \\
& 5.00 & 75 & 20.1 & 20.2 & 99.2 & \\
& Missing & 6 & 1.6 & & & \\
& Total & 377 & 100.0 & 100.0 & & \\
\hline
\end{tabular}

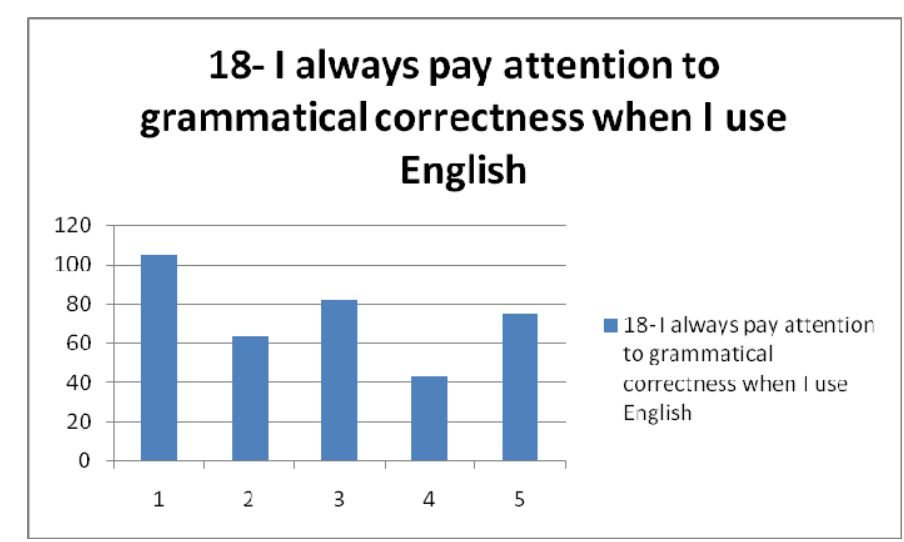

Figure 18. I always pay attention to grammatical correctness when I use English

Table 19. If I don't know all the words to say what I mean I look for synonyms and paraphrases

\begin{tabular}{lllllll}
\hline & & Frequency & Percent & Valid Percent & Cumulative Percent & Average \\
\hline \multirow{6}{*}{ Valid } & 1.00 & 160 & 43.1 & 42.7 & 42.7 & \\
& 2.00 & 93 & 25.1 & 24.8 & 67.5 & \\
& 3.00 & 69 & 18.6 & 18.4 & 85.9 & 2.06 \\
& 4.00 & 29 & 7.8 & 7.7 & 93.6 & \\
& 5.00 & 18 & 4.9 & 4.8 & 98.4 & \\
& Missing & 2 & 0.5 & & & \\
& Total & 377 & 100.0 & 100.0 & & \\
\hline
\end{tabular}




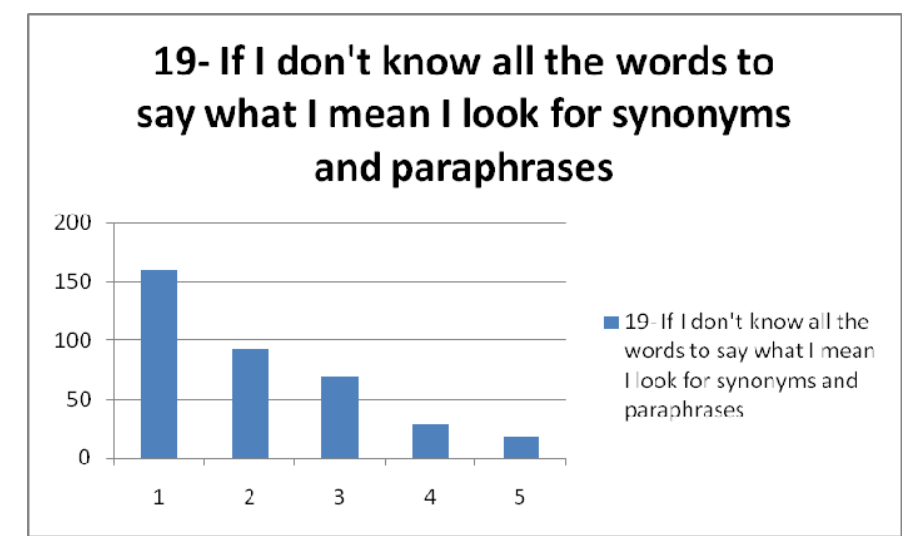

Figure 19. If I don't know all the words to say what I mean I look for synonyms and paraphrases

Table 20. I skim an academic text first to get the main idea and then read it more carefully

\begin{tabular}{lllllll}
\hline & & Frequency & Percent & Valid Percent & Cumulative Percent & Average \\
\hline \multirow{6}{*}{ Valid } & 1.00 & 156 & 41.6 & 42.2 & 42.2 & \\
& 2.00 & 84 & 22.4 & 22.7 & 64.9 & \\
& 3.00 & 65 & 17.3 & 17.6 & 82.4 & 2.19 \\
& 4.00 & 27 & 7.2 & 7.3 & 89.7 & \\
& 5.00 & 36 & 9.6 & 9.7 & 99.5 & \\
& Missing & 7 & 1.9 & & & \\
& Total & 377 & 100.0 & 100.0 & & \\
\hline
\end{tabular}

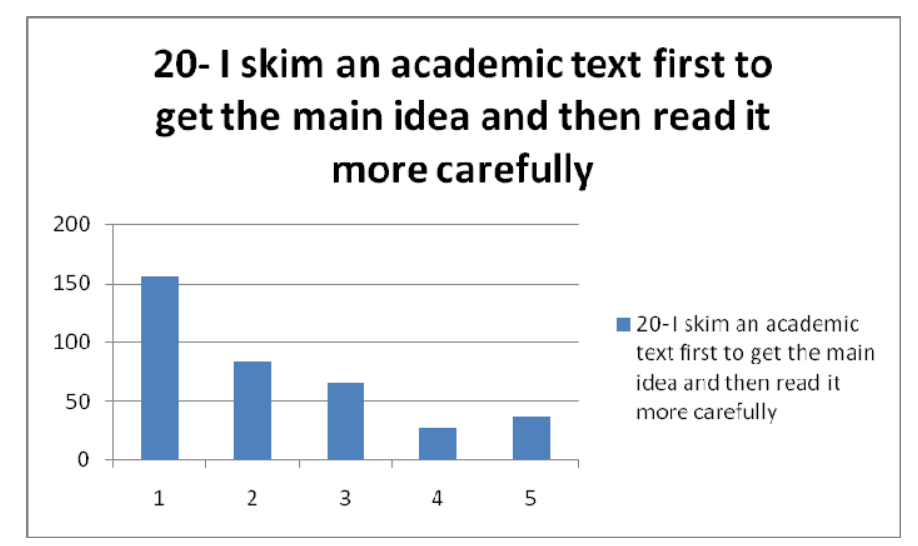

Figure 20. I skim an academic text first to get the main idea and then read it more carefully

Table 21. If I don't know words in a text, I see if I can break them into parts I can identify

\begin{tabular}{lllllll}
\hline & & Frequency & Percent & Valid Percent & Cumulative Percent & Average \\
\hline \multirow{6}{*}{ Valid } & 1.00 & 118 & 31.9 & 32.2 & 32.2 & \\
& 2.00 & 53 & 14.3 & 14.4 & 46.6 & \\
& 3.00 & 105 & 28.4 & 28.6 & 75.2 & 2.57 \\
& 4.00 & 16 & 4.3 & 4.4 & 79.6 & \\
& 5.00 & 61 & 16.5 & 16.6 & 96.2 & \\
& Missing & 17 & 4.6 & 3.8 & & \\
& Total & 377 & 100.0 & 100.0 & & \\
\hline
\end{tabular}




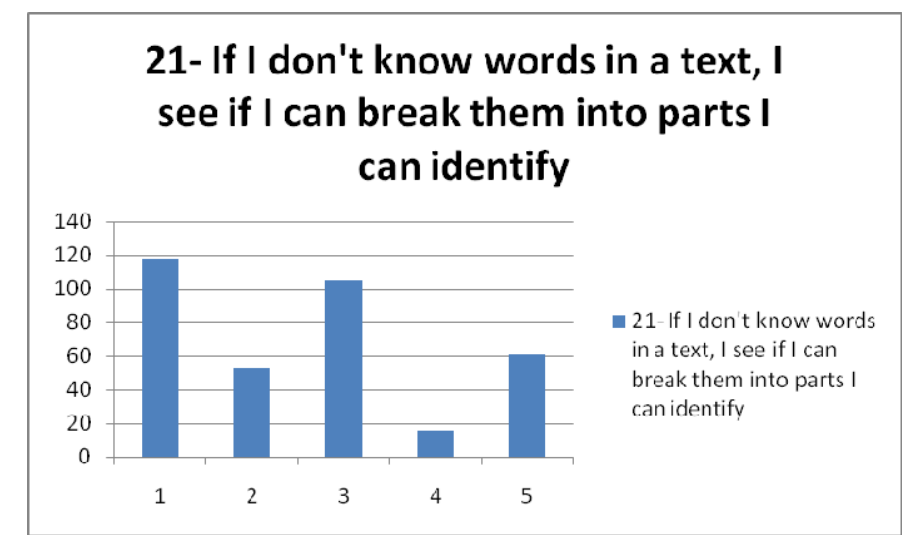

Figure 21. If I don't know words in a text, I see if I can break them into parts I can identify

However, there are still students who had a mix attitude towards learning English as the second language. Table 22 shows 122 students kept their views neutral and only 56 individuals agree that they make any effort related to learning English vocabulary on a regular basis as illustrated in the table below. At the same time very few students agreed that they make notes related to the new words they encounter while learning English. Table 26 shows that there were 108 individuals who stated that they neither read books nor newspapers in English for bringing an improvement or learning English language. On the contrary Table 26 shows that there were 150 individuals who stated that they use context for guessing the meaning of unknown words. Therefore, questionnaire results showed the attitude of students especially in the Engineering University of Saudi Arabia towards learning English language.

Table 22. I review vocabulary regularly so I don't forget new words

\begin{tabular}{lllllll}
\hline & & Frequency & Percent & Valid Percent & Cumulative Percent & Average \\
\hline \multirow{6}{*}{ Valid } & 1.00 & 56 & 15.3 & 14.8 & 14.8 & \\
& 2.00 & 50 & 13.6 & 13.2 & 28.0 & \\
& 3.00 & 122 & 33.2 & 32.2 & 60.2 & 3.22 \\
& 4.00 & 38 & 10.4 & 10.0 & 70.2 & \\
& 5.00 & 103 & 28.1 & 27.2 & 97.4 & \\
& Missing & & 5.6 & & & \\
& Total & 377 & 100.0 & 100.0 & & \\
\hline
\end{tabular}

\section{2-I review vocabulary regularly so I don't forget new words}

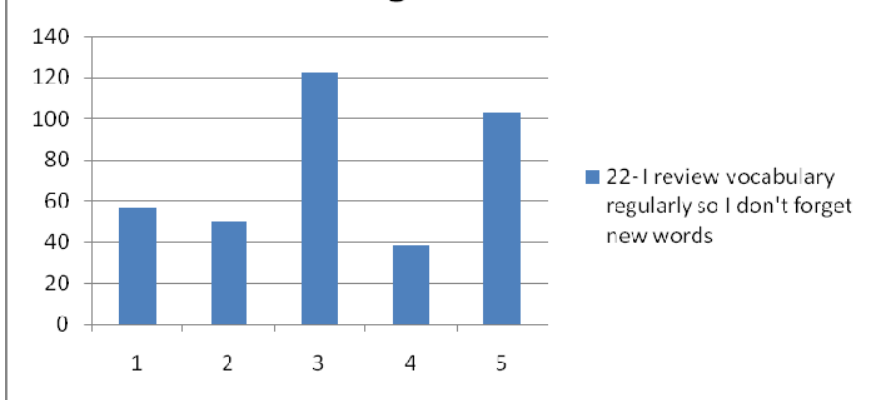

Figure 22. I review vocabulary regularly so I don't forget new words 
Table 23. I make notes of new words I encounter when reading or listening

\begin{tabular}{lllllll}
\hline & & Frequency & Percent & Valid Percent & Cumulative Percent & Average \\
\hline \multirow{4}{*}{ Valid } & 1.00 & 80 & 21.1 & 21.8 & 21.8 & \\
& 2.00 & 46 & 12.1 & 12.5 & 34.3 & \\
& 3.00 & 112 & 29.6 & 30.5 & 64.9 & 3.03 \\
& 4.00 & 45 & 11.9 & 12.3 & 77.1 & \\
& 5.00 & 86 & 22.7 & 23.4 & 100.5 & \\
& Missing & 10 & 2.6 & & & \\
& Total & 377 & 100.0 & 100.0 & & \\
\hline
\end{tabular}

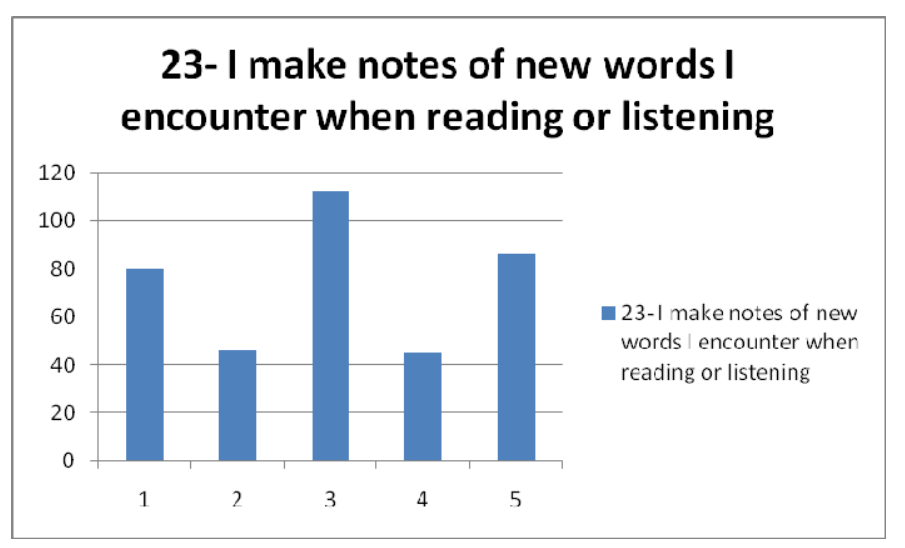

Figure 23. I make notes of new words I encounter when reading or listening

Table 24. I plan out in advance what I want to say

\begin{tabular}{lllllll}
\hline & & Frequency & Percent & Valid Percent & Cumulative Percent & Average \\
\hline \multirow{6}{*}{ Valid } & 1.00 & 159 & 43.3 & 42.2 & 42.2 & \\
& 2.00 & 61 & 16.6 & 16.2 & 58.4 & \\
& 3.00 & 93 & 25.3 & 24.7 & 83.0 & 2.19 \\
& 4.00 & 26 & 7.1 & 6.9 & 89.9 & \\
& 5.00 & 28 & 7.6 & 7.4 & 97.3 & \\
& Missing & 0 & & & & \\
& Total & 377 & 100.0 & 100.0 & & \\
\hline
\end{tabular}

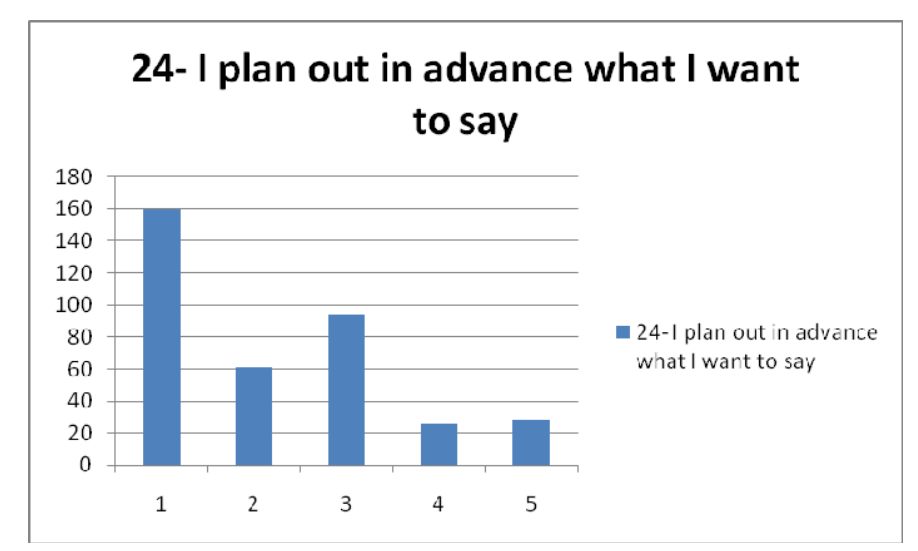

Figure 24. I plan out in advance what I want to say 
Table 25. I read books and newspapers in English just for fun

\begin{tabular}{lllllll}
\hline & & Frequency & Percent & Valid Percent & Cumulative Percent & Average \\
\hline \multirow{6}{*}{ Valid } & 1.00 & 58 & 15.4 & 15.8 & 15.8 & \\
& 2.00 & 36 & 9.5 & 9.8 & 25.6 & \\
& 3.00 & 102 & 27.1 & 27.8 & 53.4 & 3.35 \\
& 4.00 & 63 & 16.7 & 17.2 & 70.6 & \\
& 5.00 & 108 & 28.6 & 29.4 & 100.0 & \\
& Missing & 10 & 2.7 & & & \\
& Total & 377 & 100.0 & 100.0 & & \\
\hline
\end{tabular}

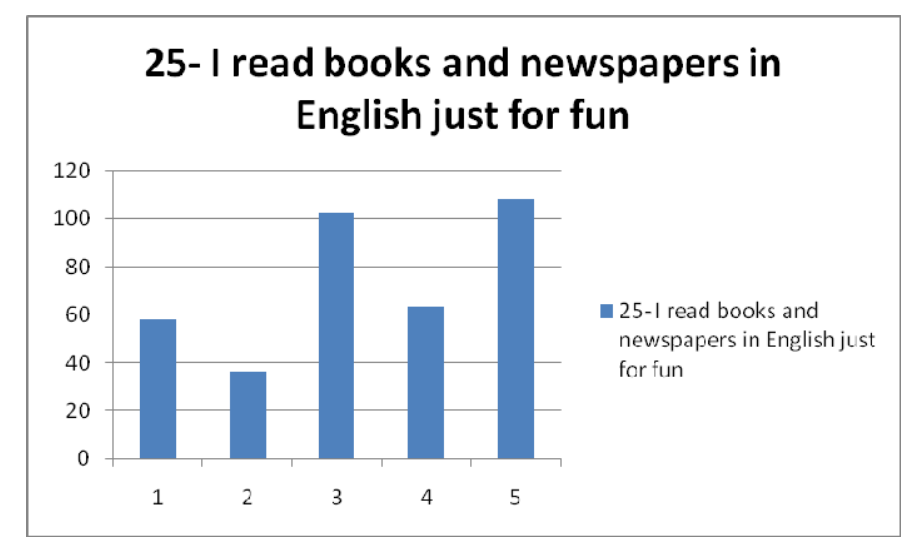

Figure 25. I read books and newspapers in English just for fun

Table 26. I use the context to help me guess the meaning of unknown words

\begin{tabular}{lllllll}
\hline & & Frequency & Percent & Valid Percent & Cumulative Percent & Average \\
\hline \multirow{6}{*}{ Valid } & 1.00 & 150 & 40.9 & 39.6 & 39.6 & \\
& 2.00 & 90 & 24.5 & 23.7 & 63.3 & \\
& 3.00 & 76 & 20.7 & 20.1 & 83.4 & 2.19 \\
& 4.00 & 16 & 4.4 & 4.2 & 87.6 & \\
& 5.00 & 37 & 10.1 & 9.8 & 97.4 & \\
& Missing & & & & & \\
& Total & 377 & 100.0 & 100.0 & & \\
\hline
\end{tabular}

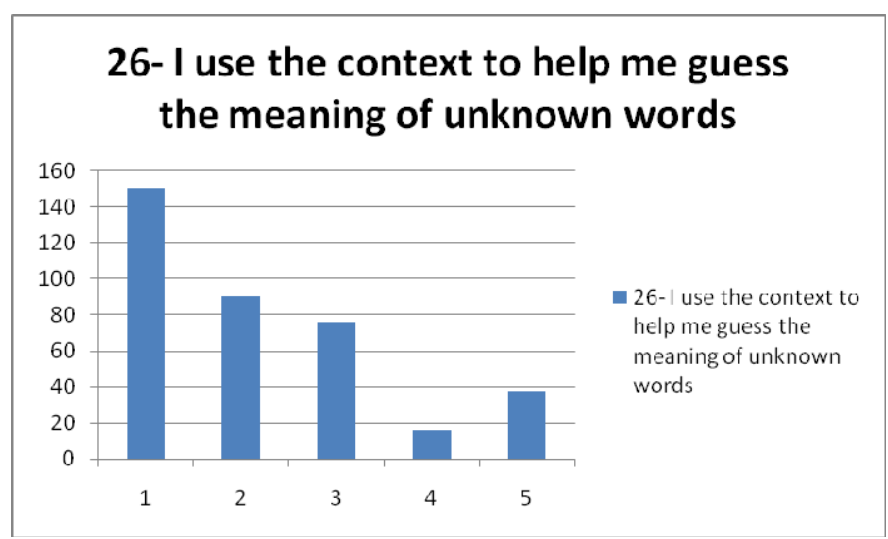

Figure 26. I use the context to help me guess the meaning of unknown words 
At the same time interviews were also conducted from 16 students for finding out their views related to learning English language especially by the Students of Engineering University. All the interviews stated that practicing and using different tools such as movies, books and newspapers can facilitate in learning English language. However, the curriculum provided in the University is insufficient and teachers are not highly qualified. It was also mentioned by the interviewees that strategies through which students can have a positive attitude towards learning English language are to develop the academic program and update the English course.

It is important for the universities that they must use information technology for attracting and enhancing English language within the Students of especially the Engineering University. Interviewees were also inquired related to the habit of students that have changed as a result of post secondary education that led towards an impact on the attitude of students towards learning English. In perspective with the School of Engineering, interviewees were asked related to the usefulness and effectiveness of English for them. Then, suggestions were inquired by the interviewees related to bringing improvement in the quality of English Programs provided within the university. Interviewees were asked related to the importance of speaking and writing English in their careers and education. However, discussion will provide important points related to the attitude of students in particular students within Engineering University towards learning English language.

\section{Discussion}

English for Specific Purposes has its basis in an investigation of the purposes of the learner and sets of communicative needs arising from them. The kind of English that is taught should base upon the interest and requirements of the students. The research study of Brown (2009) illustrated that English for Specific Purpose is not a new terminology but it is a new approach that emphasizes teaching. Moreover, the emphasis of this style is on the learner rather than on the teacher. It can be stated that attitude of the students has a significant role in understanding the attitude of the students related to learning of any foreign language specifically English. Another research study was conducted by Busch (2010) that has identified the fact that learners have various needs and interests which could have a direct influence on the motivation level and ultimately it could have an impact on the effectiveness of courses provided to the students.

In order to provide specific course purpose it is significant that text that is used within a course is related to or from the learners' areas of specialization. There are two main divisions in context of which English is being learned for a specific purpose. Firstly, it has been identified that English is learned for overcoming occupational purposes (Gan, 2009). Thus, English is being learned when students need to use it as part of their work.

The research study conducted by Hagler (2014) has conducted a research for finding out the attitudinal factors that have an impact among the Saudi university Students. This research identifies that positive attitude of students lead towards motivation among the students for learning English as a second language while studying at a university.

On the other hand, another specific purpose for which English is being learned or students especially in the Saudi Engineering University are interested to learn because some students need English in their studies. For example, English for Science, Technology and Engineering is important and it helps students in serving various purposes that are connected with their specialization (Hartel \& Vittori, 2010). Therefore, students in the engineering field especially in Saudi Arabia, as a result of their professional needs are motivated towards learning English as it provides a stock of vocabulary items, grammatical forms and functions that are common to the study of Engineering.

Despite of previous academic and technical facts related to the importance of English for Specific Purpose and positive attitude of Saudi students. There are still no ESP courses being offered in many Engineering Universities within Saudi Arabia. The research work of (MacIntyre, 2007) has stated that there is need for engineering students to learn English language. However, there are several reasons due to which engineering universities of Saudi Arabia are unable to provide an English course or teach in a manner that is able to produce fruitful results for the students. Moreover, it was identified in the research study of (Pan \& Block, 2011) that many students still had a negative attitude towards learning English because the mode through which this course was taught in many universities of Saudi Arabia was conventional.

It was critically evaluated by the researchers Riley (2009) that there are several ways through which changes can occur within the attitude of students towards learning English as a second language. It was identified that universities that used information technology were able to have a positive attitude of the students as compared to the universities that provided ESP through conventional methods.

Globalization also had a significant impact on the motivation level of the students having different fields of 
specialization. The research study of Alhuqbani (2014) took into consideration a group of cadets for identifying their attitude towards learning English as a second language. It was found that there was a need for bringing improvement in the English course forenhancing the motivation level among individuals within Saudi Arabia. Thus, Saudi Engineering students in order to achieve competitive advantage are motivated towards learning English so that they can interact with individuals belonging to different communities or countries. In addition, it has also been identified that students especially the ones in Medical or Engineering Universities of Saudi Arabia have a positive attitude towards learning English because it brings improvement in the limited communicative abilities among the students (Wong, 2010). The cognitive ability of individuals also has a direct impact on their capability to learn new languages. The students, who have a greater ability to achieve high academic performances, also have greater linguistic development capabilities. The similarities which are present within the native langue and the new language being learnt by the individuals, also has an impact on the learning process (Beebe \& Giles, 1984).

Therefore, critical evaluation conducted by researchers in the past have stated that attitude do have an impact on learning English among Saudi Engineering students. There has been a drastic change in the attitude of students but still many Universities are unable to provide English courses as a result of which many students still are not motivated towards learning English. Further analysis is being conducted related to attitude of specifically Engineering Students of Saudi Arabia.

On the basis of the information gathered from various sources it is clearly discussed that there are a lot of variations in the attitude of students in learning English. Responses mentioned in the survey and interviewees were able to illustrate that Universities especially the ones specializing in the field of engineering are unable to provide extensive courses for English language due to which students are not interested in learning English as a second language. It is also examined that students who have a specific purpose that is professional are motivated and interested towards learning English language. Moreover, students especially the ones having engineering as their specialization are interested in learning English language; but, these students are not motivated towards making extra efforts for bringing improvement in their English language. In addition, it has also been identified that many universities do not have an updated or an extended English syllabus due to which students are not interested in learning English language. At the same time, it was also found from the data collected that students in universities that use information technology for teaching English courses have more interest of the students for learning English language.

It has been emphasized that students need and interest are related to their backgrounds, experiences and ability of the students to learn and enhances their self-confidence. So, that it leads towards positive attitudes for learning English proficiency. As discussed, engineering learners must modify what they acquire in engineering materials that are used in general English. Thus, learning English helps engineering students in understanding the structure and vocabulary used in their courses.

\section{Conclusion}

Concluding the research, it is clear that students within Saudi Arabia are reluctant towards learning English language. Students are not motivated for making extra efforts towards learning or making improvement in their English language. In a nutshell, it has been identified that students are relying on their universities to provide them with a complete English language course so that they can easily learn English for only certain specific purposes. There are many universities in Saudi Arabia that are not able to proper English language courses; neither have they had teachers that could provide best services to the students. Moreover, universities of Saudi Arabia are using conventional methods of teaching due to which students are not interested in learning English. However, there is a certain portion of students who are interested in improving and learning English language because it facilitates in achieving their professional purpose and improves their communicating abilities. It is revealed in this research that poor English background, fear of grammatical mistakes and lack of confidence are major contributors in having an impact on the learners of English language. Therefore, study supports the theory that engineering students attitudes towards learning English is changing with the passage of time.

\section{References}

Alhuqbani, N. M. (2014). Teaching English to Saudi Police Cadets: An Evaluation Study. Journal of Language Teaching and Research, 5(5), 999-1008. http://dx.doi.org/10.4304/jltr.5.5.999-1008

Amuzie, G. L., \& Winkie, P. (2009). Changes in language learning beliefs as a result of study abroad. System, 37(3), 366-379. http://dx.doi.org/10.1016/j.system.2009.02.011

Barcelos, A. M. F., \& Kalaja, P. (2011). Editorial: Introduction to beliefs about SLA revisited. System, 39(3), 
281-289. http://dx.doi.org/10.1016/j.system.2011.07.001

Bateman, B. E. (2008). Student teachers' attitudes and beliefs about using the target language in the classroom. Foreign Language Annals, 41, 11-28. http://dx.doi.org/10.1111/j.1944-9720.2008.tb03277.x

Beebe, L. M., \& Giles, H. (1984). Speech-accommodation theories: A discussion in terms of second-language acquisition. International Journal of the Sociology of Language, 1984(46), 5-32. http://dx.doi.org/10.1515/ijsl.1984.46.5

Bernat, E., Carter, N., \& Hall, D. (2009). Beliefs about language learning: Exploring links to personality traits. University of Sydney Papers in TESOL, 4, 115-148.

Borg, S. (2011). The impact of in-service teacher education on language teachers' beliefs. System, 39(3), 370-380. http://dx.doi.org/10.1016/j.system.2011.07.009

Brown, A. (2009). Students' and teachers' perceptions of effective foreign language teaching: A comparison of ideals. The Modern Language Journal, 93(1), 46-60. http://dx.doi.org/10.1111/j.1540-4781.2009.00827.x

Busch, D. (2010). Pre-service teacher beliefs about language learning: The second language acquisition course as an agent for change. Language Teaching Research, 14(3), 318-337. http://dx.doi.org/10.1177/1362168810365239

Gan, Z. (2009). Asian learners' re-examined: An empirical study of language learning attitudes, strategies and motivation among mainland Chinese and Hong Kong students. Journal of Multilingual and Multicultural Development, 30(1), 41-58. http://dx.doi.org/10.1080/01434630802307890

Hagler, A. (2014). Attitudinal factors affecting learning among Saudi university students. Learning and Teaching in Higher Education. Gulf Perspectives, 11(1). Retrieved from http://the.zu.ac.ae/index.php/lthehome/ article/download/115/83

Hartel, M., \& Vittori, O. (2010). Studies beginn an der WU: Studieneingangsbefragung im Studienjahr 2009/2010. Retrieved from http://www.wu.ac.at/academicstaff/info/facts/

MacIntyre, P. D. (2007). Willingness to communicate in the second language: Understanding the decision to speak as a volitional process. Modern Language Journal, 91(4), 564-576. http://dx.doi.org/10.1111/j.1540-4781.2007.00623.x

Maxwell, J. A. (2012). The importance of qualitative research for causal explanation in education. Qualitative Inquiry, 18(8), 655-661. http://dx.doi.org/10.1177/1077800412452856

Pan, L., \& Block, D. (2011). English as a "global language" in China: An investigation into learners' and teachers' language beliefs. System, 39(3), 391-402. http://dx.doi.org/10.1016/j.system.2011.07.011

Riley, P. A. (2009). Shifts in beliefs about second language learning. RELC Journal, 40, 102-124. http://dx.doi.org/10.1177/0033688208101448

Wong, M. S. (2010). Beliefs about language learning: A study of Malaysian pre-service teachers. http://dx.doi.org/10.1177/0033688210373124

\section{Copyrights}

Copyright for this article is retained by the author(s), with first publication rights granted to the journal.

This is an open-access article distributed under the terms and conditions of the Creative Commons Attribution license (http://creativecommons.org/licenses/by/3.0/). 